\title{
Czasownikowe wykładniki fałszu $z$ inherentną oceną działań agensa
}

Słowa klucze: semantyka, wartościowanie, leksykalne wykładniki fałszu Keywords: semantics, evaluation, lexical exponents of falsehood

Przedmiotem artykułu są czasownikowe wykładniki fałszu. Za cel stawiam sobie wskazanie właściwości semantycznych jednostek z tej klasy, zawierających w swej treści komponent oceniający. Przedtem krótko scharakteryzuję klasę czasowników fałszu, a także wyjaśnię, jak rozumiem pojęcie inherentnej oceny w obrębie treści jednostki języka. W dalszej części artykułu omówię bliżej dwie podklasy czasownikowych wykładników fałszu zawierających dezaprobatę. W końcowej części pracy skomentuję wykorzystane w opracowaniu sposoby identyfikowania elementu oceny w obrębie treści jednostek języka.

\section{Czasownikowe wykładniki fałszu}

Mówiąc o czasownikowych wykładnikach fałszu (w skrócie VF), mam na myśli prymarnie rematyczne jednostki predykatywne, które implikują krytykę przypisania czemuś jednej ze wzajemnie wykluczających się askrypcji. Są to m.in. czasowniki: blefować, że p, podrobić coś, okantować kogoś, przeinaczyć coś, zafatszować coś, wypaczyć coś, fantazjować, że p, kręcić, że p, 
nabrać kogoś, że p, skłamać, że p, symulować, że p, ściemniać, że p, zetgać, ze p, koloryzować coś, minać się z prawda, otgać kogoś, pomylić się co do czegoś, pomylić się w czymś, pomylić kogoś/coś z kimś/czymś, sfatszować coś, sfingować coś, wyssać coś z palcal.

Nietrudno zauważyć, że jest to szeroka i semantycznie niejednorodna klasa, a wymienione czasowniki to tylko niektóre z jej elementów. W obrębie klasy czasowników przesądzających fałsz znajdą się zarówno takie, które wymagają składniowo argumentu propozycjonalnego ${ }^{2}$, jak i te, które łączą się wyłącznie z frazą nominalną (por. Zaucha 2015: 112-114). Inną właściwością wyrażeń $\mathrm{z}$ tej klasy jest obecność $\mathrm{w}$ ich treści informacji o aktualności aktu mowy wprowadzającego fałsz. Ze względu na nią czasowniki fałszu dzielą się na implikujące aktualne odezwanie się autora fałszu (skłamać, że p, koloryzować coś) i niezawierające przesądzenia o odezwaniu się agensa (sfatszować coś, pomylić się w czymś) (por. Zaucha 2015: 113-115). Krzyżując oba kryteria, można wskazać cztery podtypy czasowników fałszu: 1. wymagające frazy propozycjonalnej i wykluczające milczenie agensa (w skrócie: VFL + sent.); 2. wymagające frazy propozycjonalnej i niewykluczające milczenia agensa (VFS + sent.); 3. niepropozycjonalne, wykluczające milczenie agensa (ściślej przyłączenie fraz milczqc/ $w$ milczeniu) na zasadzie sprzeczności lub niespójności (VFL - sent.); 4. niewymagające uzupełnienia propozycjonalnego i dopuszczające milczenie agensa (VFS - sent.)

Obecność oceny w treści czasowników fałszu jest niezależna od typu składniowo-semantycznego na tym poziomie ogólności. Jest ona związana z trybem mówienia, do którego odnosi się dana jednostka oraz ze szczegółowymi różnicami w strukturze semantycznej wyrażeń tej klasy. Element ewaluatywny w treści danego wykładnika fałszu ma związek z przesądzeniem co do:

1 Wyliczenie to nie zawiera pełnego kształtu jednostek języka współtworzących klasę wykładników fałszu. Sprawa właściwej formy jednostki języka wymaga każdorazowo osobnej analizy. W tym miejscu chcę jedynie wstępnie zasygnalizować różnorodność leksykalną w obrębie pola wykładników fałszu.

2 Składniowa klasyfikacja czasowników wymagających argumentu zdarzeniowego, w tym części czasowników fałszu, została przedstawiona przez Z. Zaron (1980: 101-102). W opracowaniu tym kryterium podziału na najogólniejszym poziomie stanowią właściwości składniowe. Dlatego wiele jednostek implikujących fałsz nie mogło być uwzględnionych. Z kolei jednostki takie, jak truć/ględzić komuś znalazły się w tym samym podtypie, co czasowniki fałszu. 
- określonej wiedzy autora fałszywej wypowiedzi lub jej brakiem;

- intencji wyrządzenia krzywdy komuś;

- intencji świadomego dążenia do wprowadzenia kogoś w błąd.

Poszczególne podklasy, dzieląc część ładunku treściowego, nie muszą współdzielić miejsca przyłożenia (tj. zakresu) negatywnej (na ogół) oceny. Innymi słowy, dezaprobata w obrębie wykładników fałszu może dotyczyć różnych zjawisk.

\section{O wartościowaniu za pomocą wykładników fałszu}

Sprawa wartościowania od dawna leży na sercu polskim lingwistom. Wartości były i są przedmiotem zainteresowań, studiów i działań popularyzatorskich J. Puzyniny (1992, 1993, 1997, 2004, 2007, 2008, 2013). Liczne opracowania na ten temat powstają w środowisku lubelskim (Bartmiński 1993, 2003, 2006, 2012). Wartościom poświęcała swoje komentarze A. Wierzbicka (m.in. 2006, 2014, 2015), wskazując na komponent aprobaty lub dezaprobaty ('dobry'/ 'zły') w eksplikacjach licznych pojęć. O wartościowaniu (w szczególności prawdziwościowym) pisał także A. Bogusławski (2005, 2011). Zwrócił on uwagę na szczególną pozycję prawdomówności w przestrzeni aksjologicznej. Okazuje się, że podejmując próbę pochwały świadomego mówienia nieprawdy, nie możemy zarazem nie pochwalić jej przeciwieństwa - prawdy (por. Bogusławski 2005: 51-74).

Dostrzeżony przez A. Bogusławskiego swoisty ,prymat” aprobaty prawdomówności widoczny jest również w liczebności leksykalizacji właściwych polszczyźnie. Wśród wykładników fałszu z trudem można znaleźć jednostki języka polskiego zawierające pozytywną ocenę. Jako przykłady do głowy przychodzą mi wyrażenia: zadać kłam czemuś, odkłamać coś, sprostować coś. Można tu dostrzec symetrię w stosunku do wykładników prawdomówności - w tym wypadku zjawiskiem rzadkim jest negatywna ocena. Jednym z nielicznych przykładów powiązania dezaprobaty z orzeczeniem mówienia prawdy jest treść czasownika np. sypnqć kogoś $\approx$ 'zdradzić czyjś udział w czymś zagrożonym represją'.

Podejmując temat wartościowania w kontekście czasownikowych wykładników fałszu, chcę skupić się nie tyle na samym zjawisku, ile na semantycznej różnicy między poszczególnymi podklasami czasowników fałszu. Już fałsz nie jest aksjologicznie obojętny, a i jego leksykalne eksponenty są 
uwikłane w ocenę w rozmaity sposób. Różnice te pokażę, zderzając ze sobą podklasy czasownikowych wykładników fałszu.

W swoim wywodzie abstrahować będę od zasadniczej i z konieczności negatywnej oceny samego zjawiska mówienia czegoś wbrew własnej wiedzy. Po drugie, nie będę koncentrować się również na ocenie wypowiedzi ze względu na jej relację do rzeczywistości. Taka ocena stanowi istotę wykładników fałszu. Sam predykat jest fatszem/ fatszywy służy do tego, żeby wartościować wypowiedzi właśnie ze względu na ich izomorficzną relację do rzeczywistości opartą na funktorze wiedzieć, $\dot{z} e^{3}$. Ten rodzaj oceny nazywany jest wartościowaniem prawdziwościowym lub logicznym.

Skupię się za to na wartościowaniu związanym ściśle z jakąś inną (nie - prawdziwościową) predykacją, składającą się na treść poszczególnych jednostek. To właśnie mam na myśli, mówiąc o inherentnej ocenie działań agensa. Różnica, o którą mi chodzi, widoczna jest w kontraście neutralnej konstrukcji powiedziat(a) nieprawdę z jednej strony i oceniających wyrażeniach oszukat(a) kogośs/sktamat(a), że_lub oczernić kogoś przed kimś, wypaczyć coś z drugiej. Kontrast ten będzie przedmiotem rozważań w dalszej części artykułu.

Fakt leksykalizowania ocen przez niektóre jednostki języka służące orzekaniu innych właściwości został opisany przez A. Bogusławskiego i E. Drzazgowską (2016: 593) w kompendium poświęconemu historii myśli teoretycznej o języku:

Tymczasem komponent oceny naprawdę zajmuje miejsce osobne; jest to miejsce, w którym pewne ogólne p oj ę c i e opisowe użyte w charakterystyce pewnego obiektu, nie zaś to, co np. robi konkretnie opisywana osoba, staje się obiektem podlegającym z góry przyjętemu w danej konwencji językowej zaliczeniu, ze względu na jego treść przedmiotową, do rzeczy dobrych lub złych.

Myślicielem dostrzegającym owo zjawisko, aczkolwiek nieprecyzyjnie, jest zdaniem autorów opracowania, J.S. Mill (Bogusławski, Drzazgowska 2016: 593):

3 Właściwości formalne i treściowe tego funktora szczegółowo omawia A. Bogusławski w licznych swoich pracach - najpełniej w dziele $A$ study in the linguistics-philosophy interface (2007). Predyktat ktoś wie o kimśs /czymśs, że p, nie: $\sim p$ pełni fundamentalną rolę w wyjaśnieniu istoty języka i rzeczywistości. 
Z drugiej jednak strony w ostatnim zacytowanym zdaniu Milla znakomicie została uchwycona ta okoliczność, że owa osobna ocena ma status presupozycji, tzn. jest podawana w dyskursie jako nie podlegająca dyskusji, jako przyjęta wcześniej, właśnie z góry, niejako w nawiasie. Ta okoliczność wywołuje przypomniane też przez Milla fatalne zwikłania w dyskursie.

W dalszej części artykułu będę chciała wskazać te spośród czasowników fałszu, które inkorporują ocenę działania osoby, a także rozważyć jej miejsce w strukturze ich treści. Ocenie wyrażanej przez metanadawcę - aktualnego mówiącego (tego, kto używa wykładnika fałszu) podlegają, jak wspomniałam, różne momenty sytuacji leksykalizowanej przez poszczególne jednostki: po pierwsze świadomość mówienia wbrew własnej wiedzy, po drugie intencja wprowadzenia w błąd i po trzecie chęć skrzywdzenia kogoś poprzez mówienie o nim nieprawdy do osób trzecich. W zależności od podklasy czasowników fałszu inkorporowana ocena ma charakter presupozycji bądź należy do części asercyjnej w obrębie treści jednostki języka.

\section{Ocena związana z przesądzeniem określonej wiedzy agensa w zwykłym trybie mówienia}

Czasownikowe wykładniki fałszu różnią się ze względu na to, czy w ich treści zawarta jest informacja o wiedzy agensa co do tematu ocenianej wypowiedzi, czy nie. Ze skrzyżowania wiedzy metanadawcy (aktualnego mówiącego) i agensa (autora fałszu) dotyczącego powiedzenia, że p, otrzymujemy alternatywę:

M wie, że nie p i A wie, że nie $\mathrm{p}$.

lub

M wie, że nie p i nie jest tak, że A wie, że nie p.

Pierwszy układ jest charakterystyczny dla czasowników - żartować, że $p$, skłamać, że p. Drugą kombinację pojęciową znajdujemy z kolei w ładunku funkcjonalnym jednostek typu bajać/fantazjować, że p, ale też pomylić się co do czegoś, być w btędzie co do czegoś. 
Widać, że niezbywalnym punktem odniesienia dla oceny w wykładnikach fałszu jest zgłaszana wiedza aktualnego mówiącego. Wyraża ją formuła: $M$ wie, że nie $p$. Na to nakłada się jeszcze tryb dyskursu, w jakim odbyło się początkowe (potem określane jako fałszywe) powiedzenie czegoś. Jest to albo tryb mówienia żartobliwego albo mówienia serio. Rozróżnienie to wyrasta na gruncie dostrzeżonej przez A. Bogusławskiego (2004, 2005a, 2007: 429-433, 2008: 27-43) różnicy między asercyjnym powiedzieć, że p i cytacyjnym powiedzieć:_. Iloczyn obu właściwości opisuje możliwości układów treściowych charakterystycznych dla wykładników fałszu:

i. A wie, że nie p i chce być brany serio.

ii. A wie, że nie $\mathrm{p}$ i nie chce być brany serio.

iii. A nie wie, że nie p i chce być brany serio.

iv. A nie wie, czy p i nie jest tak, że chce być brany serio.

Negatywna ocena działań agensa wpisana jest w treść czasowników z pierwszej grupy, tj. takich, w których przypisaniu fałszywej z punktu widzenia mówiącego askrypcji nie towarzyszą sygnały zmiany trybu mówienia (z domyślnej, bazowej powagi na inny), a zarazem przesądza się, że autor krytykowanej wypowiedzi wie, jak się rzeczy mają. Charakterystyka ta odpowiada pojęciowo treści czasownika skłamać, że p, a także oszukaćlokłamać kogoś, że p, szkalować kogoś przed kimś, pomawiać kogoś o coś, zafatszować coś, wypaczyć coś i innych. Do grupy ii. należy np. czasownik zażartować, że p. Podklasa iii. to czasowniki pomyłki: pomylić się co do czegoś, pomylić się w czymś, rąbnać się/ walnać się/ machnać się $w$ czymś. W ostatniej z podklas (iv.) sytuują się czasowniki typu: fantazjować, że p, wymyślać, $\dot{z} e p$, bajać, że p, w wypadku których nie jest znana intencja mówiącego co do trybu mówienia, podlegającego określonej kwalifikacji gatunkowej ze strony metanadawcy.

Tezę o braku komponentu oceniającego w znaczeniu czasownika kłamać sformułowała J. Puzynina (1997: 334). Za tym rozstrzygnięciem na odmiennym metodologicznie gruncie opowiedziała się również J. Antas (1999: 150). Przeciwko obecności komponentu negatywnej oceny w pojęciu 'kłamstwa', zdaniem badaczki, przemawia to, że ankietowani użytkownicy języka nie oceniają negatywnie np. praktyki „białych kłamstw”. Zdaniem J. Antas, 
dezaprobata w wypadku kłamstwa pojawia się okazjonalnie. Nie jest stałym elementem tego pojęcia.

Tę samą konkluzję wypadnie wyprowadzić po zastosowaniu testu z frazą co sie komuś chwali zaproponowanego w pracy A. Bogusławskiego i E. Drzazgowskiej (2016: 593). Nie widać sprzeczności w zdaniu: Skłamat/ zetgat, że to baseny olimpijskie, co mu się chwali. Czy jednak test ten rzeczywiście chwyta wszelkie wypadki presuponowanej oceny? O wiele wyraźniej wydobywa on w moim przekonaniu ocenę tkwiącą w części asercyjnej w obrębie treści jednostki. Widać to na przykładzie rzeczownika kłamca, w którym ocena stanowi istotny element rematu, por. *Jest kłamca, co mu sie chwali. Jednocześnie rzeczownik ten ujmuje czynność kłamstwa holistycznie (por. dalej p. 6.3.), utrudniając zawieszenie dezaprobaty.

Jak zatem rozstrzygnąć na gruncie języka, które z czasowników presuponują dezaprobatę? Do tego celu posłużyć może fraza: Nic złego nie zrobit., poprzedzająca zdanie z czasownikiem. Jeśli porównamy sekwencje zdań (a) - (d) z różnymi wykładnikami fałszu, poprzedzonymi takim zdaniem, okaże się, że czasownik skłamać, że p różni się co do efektu sprzecznościowego względem alternatywnych wykładników fałszu. Por.:

(a) + Nic złego nie zrobił. Zażartowat tylko, że Piotr wystartuje w wyborach na prezesa klubu.

(b) + Nic złego nie zrobit. Pomylit się tylko co do wyników wyborów.

(c) + Nic złego nie zrobit. Plótt tylko, że Piotr wystartuje w wyborach na prezesa klubu.

(d) * Nic złego nie zrobił. Skłamat/zetgat tylko, że Piotr wystartuje w wyborach na prezesa klubu.

Różnicę tę wiązać trzeba właśnie z obecnością w wypadku (d) komponentu dezaprobaty. Fakt, że oceny bywają splecione na sposób presupozycji z innymi orzecznikami w obrębie treści jednostki powoduje, że umykają one testowi sprzecznościowemu. Wychwycenie tego elementu utrudnia także silne zrelatywizowanie oceny (por. Bogusławski 2011: 173-209). Dlatego w zestawie (a) - (d) istotna jest kolejność sekwencji testowej. Zdanie: Nie zrobił nic złego. dodane jako komentarz do wcześniejszej predykacji za pomocą skłamać, że p nie wywoła efektu sprzeczności. Dzieje się tak dlatego, że zakres oceny (czyli to, dla kogo i ze względu na co coś jest złe) w tym 
wypadku pragmatycznie zawęża się do mówiącego. Sytuacja, w której z perspektywy mówiącego kłamstwo w sprawie czyjegoś startu w wyborach jest dobre lub co najmniej neutralne, nie jest wykluczona.

Odmienny efekt zaobserwujemy, jeśli, antycypując, zastrzegamy, że to, o czym będzie mowa, nie jest złe. Tworzymy warunki dla implikatury: nie jest złe dla nikogo przy dowolnym celu. W ten sposób otrzymujemy sprzeczność $\mathrm{z}$ dezaprobatą presuponowaną $\mathrm{w}$ treści skłamać, że $p$ oraz jednostek implikujących to wyrażenie, a także innych wcielających układ przedstawiony w punkcie i. (por. dalej). Samo powiedzenie nieprawdy bez przesądzenia o stosownej wiedzy agensa nie wikła nas w sprzeczność. Nie wyklucza ono choćby pomyłki.

\section{Dezaprobata a intencja wyrządzenia krzywdy}

W inny sposób i z innych względów komponent oceniający pojawia się w treści czasowników typu: oczerniać kogoś, pomawiać kogoś o coś, szkalować kogoś. I one przesądzają czyjeś fałszywe mówienie o kimś ze świadomością odchodzenia od prawdy. Dodatkowo informują o celu, jaki przyświeca agensowi. Na ten element treści czasowników zwrócił uwagę J. Reszka (2001: 65): „Wydaje się, że chodzi jej (tj. osobie oczerniającej/ szkalującej JZ) o narzucenie adresatowi złej opinii o kontragensie (chodzi o obiekt oczerniania - JZ), spowodowanie, że będzie tego człowieka oceniał gorzej, niż oceniałby, gdyby nie usłyszał tego, co mówi agens".

Ze swojej strony powiedziałabym, że w działaniach, o których mowa chodzi o coś więcej niż chęć wpłynięcia na cudzą ocenę, mianowicie o intencję wyrządzenia krzywdy, zaszkodzenia. Por.: *Rosja nie chciała zaszkodzić Turcji, tylko jq oczerniała.; *Sasiadka nie chciała wyrzqdzić Annie żadnej krzywdy, szkalowała ja tylko przed pracodawca.

Negatywna ocena działań agensa w predykatach typu szkalować kogoś przed kimś uwidacznia się w zderzeniu z przysłówkiem niewinnie. Służy on do zanegowania czyjejś chęci wyrządzenia szkody. Jednocześnie jednak implikuje taką możliwość. W związku z tym przysłówek niewinnie dobrze komponuje się z wyrażeniami intencjonalnymi, które nie przesądzają chęci skrzywdzenia. Nie łączy się natomiast z predykatami nieintencjonalnymi: *Niewinnie kichnąt. i pozostaje w sprzeczności względem wyrażeń przesądzających szkodzenie: *Niewinnie pobit sqsiada. 
Jak wspomniałam, szczególny rodzaj nagany właściwy czasownikom oczerniać kogoś przed kimś, szkalować kogoś przed kimś związany jest z obecnością komponentu mówiącego o intencji wyrządzenia krzywdy obiektowi stanowiącemu temat wypowiedzi agensa. Silna aksjologizacja krzywdzenia w języku uwidacznia się poprzez brak możliwości zrelatywizowana (choćby lokalnego) tego pojęcia. Taka próba daje wyraźną sprzeczność: *Dla wspólnego dobra, skrzywdzit wroga, co mu się chwali.

$\mathrm{Na}$ marginesie zwrócę uwagę na czasownik plotkować o kimś/czymś. Pozornie bliski oczerniać kogoś przed kimś w gruncie rzeczy przynależy do odrębnego typu wykładników fałszu (typ iv.). Niesprzeczne jest połączenie tego czasownika z przysłówkiem niewinnie: + Niewinnie plotkowali o Annie.; +Sasiadka nie chciała szkodzić Annie, tylko o niej plotkowała. oraz z fraza nic złego nie zrobit: Nic złego nie zrobili. +Tylko o niej plotkowali. vs. Nic złego nie zrobiła. *Oczerniła ja tylko. Wszystko dlatego, że czasownik plotkować o kimś/czymś nie przesądza wiedzy agensa o jego własnym mówieniu wbrew faktom, fundamentalnej dla elementu oceny. Mamy tu do czynienia raczej z niewiedzą agensa co to faktycznego stanu rzeczy.

Z kolei czasowniki obmawiać kogoś, obgadywać kogoś, obsmarować kogoś przed kimś nie implikują powiedzenia czegoś sprzecznego z faktami, zachowując element dezaprobaty dotyczący mówienia nastawionego na wyrządzenie komuś szkody, por.: *Niewinnie obgadywałal obmawiałal obsmarowała Annę.

Podsumowując, dezaprobata wkomponowana w treść niektórych wykładników fałszu wiąże się z mówieniem wbrew własnej wiedzy nastawionym na wyrządzenie komuś krzywdy. Jednak inaczej niż w wypadku skłamać, że p ocena należy do części asercyjnej ładunku funkcjonalnego.

\section{Dezaprobata a intencja dezinformacji}

Komponent oceny zawarty jest również w wykładnikach leksykalizujących czyjeś (agensa, będącego inicjatorem fałszu) robienie czegoś z kimś/ czymś takie, że ktoś (adresat) jest gotów powiedzieć, że jest inaczej, niż jest W rzeczywistości. W tej grupie wykładników znajdą się czasowniki: mataczyć w czymś, zafatszować coś, wypaczyć coś, podrobić coś. Jej specyfiką jest implikacja świadomie podejmowanych czynności mających na celu wprowadzenie kogoś w błąd. Przy czym nie jest przesądzone, czy planowany skutek 
dezinformacji zaszedł, czy nie. Ważne jest za to, że czynność ta przeprowadzana jest przez agensa ze świadomością celu.

Dobrym narzędziem do wydobycia intencjonalności i sekwencyjności w obrębie treści jednostek nazywających działanie dezinformujące jest przysłówek niechcacy. Gruntowna analiza semantyczna i składniowa tego modyfikatora została przeprowadzona w pracy I. Duraj-Nowosielskiej (2012). Autorka zwraca uwagę na agentywność, prostotę (w opozycji do złożoności opisywanej akcji) oraz niepożądaność rezultatu czynności, do której odnosi się modyfikator. To, że nie może on być dodany do czasowników z grupy mówiącej o dezinformacji (por.: *Niechcacy zafatszowat dane liczbowe. vs. +Niechcacy przekręcit dane liczbowe.; *Niechcacy podrobit dokumenty. *Niechcacy mataczyt $w$ śledztwie.), ma swoje źródło w kluczowej dla niechcacy negacji elementu wolitywnego. Pozostaje on w sprzeczności z celowością i chęcią spowodowania fałszywego mniemania u adresata wypowiedzi agensa przesądzaną przez czasowniki typu mataczyć w czymś, podrobić coś. Inaczej rzecz się ma np. w wypadku predykatów wprowadzić $w$ błqd kogoś i wpuścić kogoś w maliny: +Niechcacy wprowadził go w bład.; +Niechcacy wpuścit ich w maliny. Nie przesądzają one chęci oszukania kogoś. Ich zasadniczym tematem jest skutek pewnych działań agensa, nie mówią nic o jego intencjach.

Z kolei świadomość agensa co do charakteru jego działań, w szczególności celowość działań dezinformujących daje się wychwycić za pomocą testu sprzecznościowego opartego na frazie $w$ dobrej wierze. Idiom ten łączy się z nazwami czynności, które są bądź neutralne, bądź obciążone dezaprobatą, ale nie przesądzają złych intencji względem kogokolwiek. Możemy powiedzieć: Sktamat, że to baseny olimpijskie $w$ dobrej wierze., ale nie powiemy: *Wypaczyt sens tej wypowiedzi w dobrej wierze.; *Mataczyt w dobrej wierze. Efekt sprzecznościowy powstaje na styku implikacji braku złego zamiaru (fraza $w$ dobrej wierze) i złej intencji (czasowniki fałszu) względem pacjensa.

Podobnie zachowają się czasowniki z omówionej wcześniej grupy: *Szkalowat/ oczerniat ja $w$ dobrej wierze. Obie grupy czasowników skierowanych przeciwko komuś różni ujęcie pacjensa - obiektu krzywdy. W grupie typu oczerniać kogoś przed kimś jest on wskazany składniowo - stanowi bezpośrednie uzupełnienie składniowe jednostki. W wypadku czasowników mówiących o dezinformowaniu bezpośrednim obiektem działania agensa jest pewna treść. Dopiero w dalszej kolejności, chodzi o tego, który ma nabrać 
błędnego przekonania. Na marginesie warto zauważyć, że niektóre czasowniki z tej grupy wcale nie implikują bezpośredniego kłamstwa: +On mataczyt $w$ tej sprawie, ale nie skłamat.; +Wypaczyt sens jej wypowiedzi, ale nie sktamat.

Negatywna ocena w wypadku nazw działań dezinformujących ma swoje źródło w świadomym dążeniu agensa do określonego skutku dezinformacyjnego wobec kogoś. O szkodliwości działania opisywanego przez czasowniki z tej grupy i obciążeniu odpowiedzialnością za nią agensa świadczy sprzeczność układów tych czasowników z przysłówkiem niewinnie: *Niewinnie wypaczyt te ideę.; *Niewinnie mataczyt $w$ śledztwie.; *Niewinnie sfatszowat wyniki.

W tle omawianej grupy czasowników pozostają dwie jednostki: czasownik nabrać kogoś, że p i przemilczeć coś przed kimś. Obie, choć wiążą się z dezinformowaniem, nie należą do omawianej klasy z ważnych względów. Brak komponentu oceniającego w wypadku nabrać kogoś, że p to efekt braku informacji o intencji agensa bycia wziętym serio. Wyrażenie to należy do czasowników do grupy ii. wraz z czasownikiem żartować, że p. Mogłoby się wydawać, że do grupy czasowników mówiących o wprowadzeniu kogoś w błąd należeć będzie również czasownik przemilczeć coś przed kimś. Analizę składniową i semantyczną tej jednostki, wydobywając jej pełen kształt, przedstawiła C. Heliasz (2007). Autorka słusznie nie wskazała elementu oceniającego jako składnika treści tej jednostki. Ewentualna dezaprobata, która wiąże się z przemilczeć coś przed kimś, nie ma charakteru semantycznego. Czasownik ten mówi o sytuacji naruszającej jeden z kanonów konwersacyjnych - mówienia wyczerpującego. Dlatego nagana związana z przemilczeniem to fakt natury pragmatycznej. Przemilczeć coś przed kimś nie przesądza negatywnej oceny, co widać w następującym niesprzecznym spójnym logicznie układzie: Nic złego nie zrobił. + Przemilczał tę sprawę.

Reasumując, nagana względem agensa, którego działania opisuje metanadawca, związana jest z mówieniem wbrew wiedzy tego pierwszego bez sygnałów zmiany trybu wypowiedzi z bazowej na ludyczną. Ma ona dwie odsłony: bezpośrednie kłamstwo lub inne działania z intencją dezinformacji. Osobno potraktować trzeba jednostki typu szkalowaćl pomawiać kogoś przed kimś implikujące chęć skrzywdzenia kogoś. W ich wypadku komponent oceniający sytuuje się w asercyjnej części znaczenia. 


\section{Problem wydobywania komponentu oceny}

$\mathrm{Na}$ zakończenie chciałabym zwrócić uwagę na elementy warsztatowe ważne przy wydobywaniu komponentu oceniającego w obrębie treści jednostek języka. Różnorodność obiektów podlegających ocenie metanadawcy sprawia, że nie znajdziemy uniwersalnej formuły, która mogłaby posłużyć jako klucz diagnostyczny. Ocena może dotyczyć tego, co ktoś zrobił (skrzywdzić kogoś, uratować kogoś), jak to robił (delektować się czymś, żreć coś), z kim lub czym coś zrobił ( podrobił coś, mataczył w czymś). Co więcej, relatywizacja zawarta $\mathrm{w}$ komponencie oceniającym zly/dobry (argumenty za takim porządkiem tych predykatów pod względem złożoności przedstawił A. Bogusławski 2011) utrudnia przeprowadzenie testu sprzecznościowego, umożliwiając lokalne zawieszenie wartościowania. Próbę wydobycia komponentu oceniającego skomplikować może również jego pozycja $\mathrm{w}$ obrębie treści wyrażenia. Jeśli ma on charakter presupozycji, nie będzie wyraźnie kolidował z predykatywnym centrum frazy testowej. Nie znaczy to, że uchwycenie komponentu oceniającego jest niemożliwe. Konieczne jest natomiast dostosowanie chwytów testowych do specyfiki analizowanych układów treściowych.

W kolejnych punktach zbieram sformułowania testowe, wspierające wysiłek odróżnienia predykatów z oceną związaną z nieewaluatywną predykacją od jednostek neutralnych, a odnoszących się do zjawisk negatywnie ocenianych.

\subsection{Przedmiot oceny}

Wartościowanie w polu czasownikowych wykładników daje się uchwycić poprzez testy zbudowane na wyrażeniach niekompatybilnych z pozytywną oceną. Wybór frazy służącej do wydobycia oceny zależy od tego, co jest jej przedmiotem: intencja agensa, skutki jego czynu czy charakter działań agensa (wrogi lub neutralny). Dodatek $w$ dobrej wierze pozwala uchwycić te jednostki (nie tylko z pola fałszu), które opisują działanie intencjonalne o zamierzonych negatywnych skutkach, por. sprzeczne: *Skrzywdzit ja $w$ dobrej wierze. vs. + Strzelit do niej $w$ dobrej wierze. $\mathrm{Z}$ kolei przysłówek niewinnie pomaga rozpoznać jednostki, które odnoszą się do działań agensa na czyjąś szkodę. Oszczerstwa w odróżnieniu od kłamstw, manipulacji czy oszustw są 
szkodliwe par excellence. Inny przysłówek - niechcacy (por. Duraj-Nowosielska 2012) wskazuje na celowość podejmowanych działań i niepożądany charakter ich skutków.

\subsection{Zakres oceny}

Przy wydobywaniu komponentu oceniającego trzeba mieć na uwadze zakres oceny. Widać to w przeprowadzonym przeze mnie teście, w którym nieobojętna jest kolejność pozycji wyrażenia testującego. Inny efekt obserwujemy, gdy fraza: nic złego nie zrobit poprzedza czasownik, przecząc presupozycji dezaprobaty: Nic złego nie zrobit. *Skłamat tylko./ Oczernit ja tylko., niż przy odwróceniu kolejności zdań w sekwencji: +Skłamał tylko. Nic złego nie zrobit. + Oczernit ja tylko. Nic złego nie zrobit. W tym wypadku ocenie podlega nie samo działanie agensa, ale stan rzeczy, który jest tego efektem i jego ocena może być przez metanadawcę minimalizowana.

\subsection{Zawieszenie dezaprobaty a holistyczność ujęcia ocenianego działania}

Na możliwość lokalnego zawieszenia oceny wiązanej z danym pojęciem wielokrotnie zwracał uwagę A. Bogusławski (m.in. 2005, 2011). Zawieszenie wartościowania sprawia, że kontekst: +Ukradt zegarek, co mu się chwali. lub analogiczny: +Oszukat bandytów czyhajacych na jego życie, co mu sie chwali. uznamy za niesprzeczny w odróżnieniu od: *Jest skończonym łobuzem, со mu się chwali. (Bogusławski, Drzazgowska 2016: 593). Ponieważ kradzież zegarka mogła posłużyć czemuś, co ktoś ocenia jako dobre (np. zdobyciu pieniędzy na lekarstwo), nie wchodzi w sprzeczność z frazą testową.

Lokalne zawieszenie wartościowania nie obejmie rzeczowników typu: złodziej, kłamca, oszust, gdyż wyrażenia te holistycznie ujmują aktywność, o którą chodzi. Implikują one stałe zachowanie pewnej osoby, stojące na przeszkodzie innym lub jej samej. Wyklucza ono tym samym relatywizację przeszkody/krzywdy, a przez to i dopowiedzenie: co się komuś chwali.

Opozycja całościowość vs. partykularność dobrze widoczna w kontraście skłamać - kłamca, ukraść - złodziej itd. nie jest zdeterminowana kategorią morfologiczną jednostki. Zawieszeniu wartościowania nie podlega np. czasownik skrzywdzić kogoś: *Skrzywdzit swojego wroga, żeby uratować swoje życie, co mu się chwali. vs. +Pokonat swojego wroga, co mu się chwali. 
W wypadku wykładników fałszu formuła co się komuś chwali wchodzi w sprzeczność z wyrażeniami nazywającymi czynności bezcelowe, na swój sposób nietrafne, por. *Pomylit się $w$ działaniu, co mu się chwali. lub *Plotkowali z upodobaniem, co im się chwali. Co ciekawe, sprzeczność nie zajdzie w zestawieniu wspomnianej frazy z czasownikami zafatszować coś, przeinaczyć coś ani też skłamać, że p. Opisują one czynności służące czemuś, niezależnie od moralnej oceny owych celów.

***

Mnogość aspektów podlegających ocenie w obrębie treści wielu jednostek języka, choćby tylko wśród czasowników fałszu, sprawia, że rozpoznawanie leksemów inherentnie oceniających przypomina czasem oddzielanie maku od popiołu. Zajęcie to nie jest jednak pozbawione perspektywy szczęśliwego zakończenia.

\section{Bibliografia}

AnTas J., 1999, O klamstwie i kłamaniu. Studium semantyczno-pragmatyczne, Kraków: Universitas.

Bartmiński J., Mazurkiewicz-Brzozowska M. (red.), 1993, Nazwy wartości. Studia leksykalno-semantyczne, Lublin: Wydawnictwo UMCS.

BARTMiński J. (red.), 2003, Język w kręgu wartości, Lublin: Wydawnictwo UMCS.

BARTMIŃSKi J. (red.), 2006, Język. Wartości. Polityka, Lublin: Wydawnictwo UMCS.

BARTMIŃSKI J. (red), 2012, Wartości w językowo-kulturowym obrazie świata, t. 1, Lublin: Wydawnictwo UMCS.

BogusŁawski A., 2004, Remarks on quotative 'saying', Studies in Polish Linguistics 1, s. 29-45.

BogusŁawski A., 2005, Veredicum laudare necesse est, vitam sustinere non est necesse, w: tegoż, Roztrzasania nadlingwistyczne, Warszawa: BEL Studio, s. $51-74$.

BogusŁawski A., 2005a, Do teorii czasownika powiedzieć, Polonica XXIV, s. 113-129.

Bogustawski A., 2007, A study in the linguistics-philosophy interface, Warszawa: BEL Studio.

Bogusıawski A., 2007a, Wiedza, fałsz, prawda: słowo o ich wzajemnej relacji, Przeglad Humanistyczny LI, z. 1, s. 1-7. 
BogusŁawski A., 2008, Semantyka, pragmatyka. Leksykografa głos demarkacyjny, Warszawa: Wyd. TAKT.

BogusŁawski A., 2011, On 'good' and 'bad', w: tegoż, Reflections on Wierzbicka's Explications and Related Essays, Warszawa: BEL Studio.

BogusŁawski A., Drzazgowska E., 2016, Język w refleksji teoretycznej. Przekroje historyczne, Warszawa: Katedra Lingwistyki Formalnej.

BoJAr B., 1996, Prawda i fałsz w języku naturalnym, w: J.J. Jadacki, W. Strawiński (red.), W świecie znaków. Księga Pamiatkowa Ku Czci Profesora Jerzego Pelca, Warszawa: PTF, s. 257-266.

Danielewiczowa M., 2002, Wiedza i niewiedza. Studium polskich czasowników epistemicznych, Warszawa: Katedra Lingwistyki Formalnej.

Duraj-Nowosielska I., 2012, Nie przypadkiem o niechcący. Szkic semantyczny, Warszawa: Wyd. UKSW.

Falkenberg G., Fries N., Puzynina J. (red.), 1992, Wartościowanie w języku i tekście, Warszawa: Wydawnictwa Uniwersytetu Warszawskiego.

Heliasz C., 2007, Próba rekonstrukcji znaczenia czasownika przemilczeć [coś] (przed [kimś]), Prace Filologiczne LII, s. 123-132.

Puzynina J., 1981, O znaczeniach czasownika „kłamać” we współczesnej polszczyźnie, Studia Semiotyczne, t. 11, s. 107-119.

Puzynina J., 1992, Język wartości, Warszawa: Wydawnictwo Naukowe PWN.

Puzynina J., 1993, O znaczeniu wartości, w: J. Bartmiński, M. Mazurkiewicz-Brzozowska (red.), Nazwy wartości. Studia leksykalno-semantyczne, Lublin: Wydaw. Uniwersytetu Marii Curie-Skłodowskiej, s. 9-21.

Puzynina J., 1997, Słowo-wartość-kultura, Lublin: Tow. Nauk. Katolickiego Uniwersytetu Lubelskiego.

Puzynina J., 2004, Problemy wartościowania w języku i w tekście, Etnolingwistyka, t. 16 , s. $179-189$.

Puzynina J., 2007, O pewnej ważnej zasadzie wartości, Poradnik Językowy, nr 4, S. $72-79$.

Puzynina J., 2008, Ideologia w języku polskim, Oblicza Komunikacji, t. 1, s. 13-22.

Puzynina J., 2013, Wartości i wartościowanie w perspektywie językoznawstwa, Kraków: Wyd. PAU.

ReszKa J., 2001, Predykaty mówienia implikujace pojęcie zła w języku polskim, Kraków: Wydawnictwo Naukowe DWN.

STĘPIEŃ M., 2010, Mówienie i prawda. O czasownikowych wykładnikach wiedzy niezweryfikowanej przez mówiqcego, Warszawa.

WierzBickA A., 2006, English: Meaning and Culture, New York: Oxford University Press. 
WieRZBicKa A., 2014, Moral absolutes and multiplicity of languages: Engaging with Ramon Gaita, w: A. Kozłowska, A. Świątek (red.), Znaczenie. Tekst. Kultura, Warszawa: Wyd. UKSW.

Wierzbicka A., 2015, Karta etyki globalnej w słowach uniwersalnych, Teksty Drugie: teoria literatury, krytyka, interpretacja 4, s. 257-279.

WoŁк M., 2012, O znaczeniu wyrażenia ktoś plecie, że_,Poradnik Językowy, z. 4, s. $27-36$.

Woєк M., 2012a, Czy pieprzyć o czymś to 'mówić głupstwa'? Kilka uwag o znaczeniu, Linguistica Copernicana 2 (8), s. 231-244.

WoŁk M., 2014, Nonsens i zjawiska pokrewne. Studium semantyczne, Olsztyn: Wydawnictwo Uniwersytetu Warmińsko-Mazurskiego.

WoŁк M., 2015, Kilka pytań o definiowanie błędu, Linguistica Copernicana 12, s. $231-244$.

ZARON Z., 1980, Ze studiów nad sktadniq i semantykq czasownika, Wrocław: Ossolineum.

ZAUCHA J., 2015, Zróżnicowanie składniowe i semantyczne czasownikowych wykładników fałszu, Linguistica Copernicana 12, s. 107-122.

\section{Verbal falsehood exponents with an evaluative component of an agent's action}

( s u m m a r y)

The aim of the paper is to indicate the class of verbal falsehood exponents with an evaluative component of an agent's action in their meaning. These are these language units which determinate that the agent ('falsehood's author') knows s/he is saying something untrue. At the same time, s/he wants to be taken seriously by her/ his addressee. There are two specific groups of falsehood verbs with disapproval. The first one includes verbs like oczerniać kogoś ( $\approx$ to blacken), pomawiać kogoś $(\approx$ to impute), szkalować kogoś $(\approx$ to slender), which introduce the concept of hurting someone. The second group consists of deceiving verbs like: mataczyć $\approx$ to machinate), podrobić coś $(\approx$ to wangle), wypaczyć coś $(\approx$ to distort $)$. In their semantic structure, the conceptual base is modified. Instead of saying something untrue they imply doing something by the so called 'falsehood initiator' that will cause formulating untrue proposition by an addressee. Still, the agent's need to be taken seriously is held. In the final section, the author comments on the ways of eliciting evaluative components in lexical meaning of language units. 